\title{
PRAWNE I POLITYCZNE KONSEKWENCJE WPROWADZENIA REPUBLIKAŃSKIEJ FORMY RZĄDÓW DLA POZYCJI USTROJOWEJ GŁOWY PAŃSTWA W NOWEJ ZELANDII ${ }^{1}$
}

\author{
Justyna Eska-Mikołajewska \\ Uniwersytet Ekonomiczny w Krakowie \\ Katedra Studiów Politycznych \\ ORCID ID: https://orcid.org/0000-0001-7681-2425 \\ e-mail: justynaeska.25@gmail.com
}

\begin{abstract}
Streszczenie: Przeprowadzona analiza dotyczy skutków prawnych i politycznych potencjalnej zmiany ustroju politycznego w Nowej Zelandii odnośnie do funkcjonowania głowy państwa. Zgodnie z postawioną tezą, specjalny status Maorysów może komplikować dalszy rozwój wydarzeń, wpływając na osłabienie chęci wprowadzenia republiki w tym państwie. W pracy wykorzystano analizę źródeł prawa i analizę krytyczną oraz metodę opisową. Tekst podzielono na dwie zasadnicze części oraz wstęp i zakończenie.
\end{abstract}

Słowa kluczowe: republika, głowa państwa, Traktat z Waitangi, Maorysi, Nowa Zelandia

\section{WSTĘP}

Nowozelandzki ustrój polityczny określony został jako monarchiczny wzorem swojej metropolii w $1841 \mathrm{r}$. Obecny porządek konstytucyjny odzwierciedla historyczne dziedzictwo najbardziej lojalnej kolonii brytyjskiej, a następnie dominium, przywiązanego do Korony jako symbolu imperialnej jedności. Nowa Zelandia, która niepodległość uzyskała dopiero w 1986 r. wraz z przyjęciem Ustawy Konstytucyjnej, poza zniesieniem izby wyższej parlamentu w 1950 r., wprowadzeniem Deklaracji Praw w 1990 r. oraz odejściem od większościowego systemu wyborczego w 1993 r., wciąż silnie związana jest ze swoim konstytucyjnym pierwowzorem. Podstawowy łącznik z Wielką Brytanią stanowi monarchia,

1 Publikacja finansowana w ramach programu Ministra Nauki i Szkolnictwa Wyższego pod nazwą „DIALOG” w latach 2019-2021 pierwotnie opublikowana na portalu przemianyustrojowe.pl. 
która pozostała rdzenna. Nieobecność tradycji republikańskiej w Nowej Zelandii dodatkowo wzmacnia brak obowiązywania formalnoprawnej konstytucji, pozwalając na kontynuację istnienia Korony w postaci tradycyjnej funkcji konstytucyjnego centrum. Pomimo, że głosy na rzecz zmiany ustrojowej w Nowej Zelandii nie są tak donośne, jak w sąsiedniej Australii, postulaty zniesienia monarchii nie słabną. Byłaby to z pewnością najdalej idąca $\mathrm{z}$ dotychczasowych refom ustrojowych, pociągająca za sobą szereg prawnych, jak i politycznych konsekwencji, zwłaszcza w odniesieniu do funkcjonowania głowy państwa.

\section{KONSEKWENCJE PRAWNE WPROWADZENIA REPUBLIKAŃSKIEJ FORMY RZĄDÓW}

Podstawowym źródłem nowozelandzkiego prawa jest konstytucja, która nie ma charakteru formalnoprawnego, lecz przyjmuje formę nieskodyfikowaną w jednym akcie prawnym. Część norm konstytucji to normy konwenansowe (conventions of the constitution) o charakterze politycznym. Zasadniczy komponent nowozelandzkiej konstytucji tworzą normy stanowione, należące do bloku ustaw konstytucyjnych. Pośród nich szczególne miejsce zajmuje Ustawa Konstytucyjna z 1986 r. [Constitution Act 1986], która odnosi się wyłącznie do naczelnych organów władzy państwowej. Regulacje dotyczące organów władzy wykonawczej umiejscowione zostały na czołowej pozycji aktu konstytucyjnego, co wynika z priorytetowego traktowania egzekutywy, rozumianej jako swoisty rdzeń władztwa monarszego w brytyjskich koloniach.

Nowa Zelandia stanowi monarchię konstytucyjną z królową lub królem jako głową państwa. Zgodnie z art. 2 Ustawy Konstytucyjnej, suweren (Sovereign) w prawie Nowej Zelandii, które to określenie nawiązuje do zasady suwerenności parlamentu tradycyjnie wyrażanej poprzez formułę ,króla w parlamencie” ("king in parliament'), jest głową państwa. Wobec Jej (Jego) Królewskiej Mości ma być używany styl oraz tytuł królewski, ogłaszany na podstawie odrębnego aktu prawnego. Królowa Nowej Zelandii w świetle art. 2 obowiązującej ustawy o tytułach królewskich z 1974 r. [Royal Titles 1974] nosi tytuł: „Elżbieta II z Łaski Bożej Królowa Nowej Zelandii oraz innych Jej Królestw i Terytoriów, Głowa Wspólnoty Narodów, Obrończyni Wiary". Postanowienie to rozciąga się również na stowarzyszone z Nową Zelandią Wyspy Cooka, Niue i Tokelau.

Ustawa Konstytucyjna powierzyła monarsze wypełnianie roli głowy państwa, nadając mu prawo wyznaczenia swojego reprezentanta w postaci gubernatora generalnego. Jest on przedstawicielem Korony, a zatem symbolu państwa, obejmującego zarówno suwerena, jak i jego osobistego przedstawiciela; ministrów Korony wewnątrz, jak i poza gabinetem; Radę Wykonawczą (Executive Council), która formalnie dysponuje uprawnieniem do doradzania suwerenowi i jego reprezentantowi, a także departamenty rządu centralnego, wykonujące uprawnienia i dyrektywy polityczne ministrów oraz ściśle kontrolowane organy publiczne, które kwalifikują się jako instrumenty rządu wykonawczego. 
Gubernator generalny, do 1917 r. określany mianem gubernatora, został powołany już w momencie ustanowienia Nowej Zelandii kolonią Korony w celu kierowania lokalną administracją. Jako urzędnik Zjednoczonego Królestwa pełnił rolę kanału komunikacji z rządem aż do $1941 \mathrm{r}$. [Scott 1962: 87]. Pierwsze zmiany statusu gubernatora nastąpiły wraz z przyjęciem ustawy o ustroju Nowej Zelandii z 1852 r. (New Zealand Constituton Act, 1852). Na mocy jej postanowień gubernator zobowiązany został do działania zgodnego z radą ministrów we wszystkich sprawach rządowych. Dla określenia pozycji ustrojowej gubernatora istotne jest wskazanie aktów prawnych zwanych Patentami królewskimi, wydawanymi od 1879 r. Obecnie obowiązujący Patent odnoszący się do urzędu gubernatora generalnego (Letters Patent Constituting the Office of Governor-General of New Zealand) przyjęto w 1983 r. (znowelizowany został w 2006 r.).

Regulacja odnosząca się do konieczności postępowania przez gubernatorageneralnego zgodnie z radą ministrów została ograniczona jedynie w ściśle określonych przypadkach. Na mocy art. 3 ust. 2 Ustawy Konstytucyjnej ustanowiono, że każde ustawowe odesłanie do gubernatora generalnego w Radzie (Governor-inCouncil) lub podobne wyrażenie zawiera odniesienie do suwerena, który działa na podstawie i za radą oraz zgodą Rady Wykonawczej. Warto dodać, że jest to organ złożony ze wszystkich ministrów rządu nowozelandzkiego, na czele którego stoi gubernator generalny. Rada Wykonawcza jest ciałem w pełni formalnym, posiadającym wyłączne uprawnienie do podejmowania decyzji i stanowienia regulacji wydawanych z upoważnienia gubernatora generalnego w Radzie.

Jako reprezentantowi suwerena, gubernatorowi generalnemu przysługują uprawnienia w obszarze władzy wykonawczej. Jednak jako osoba wypełniająca obowiązki de facto głowy państwa, posiada on również kompetencje odnośnie do funkcjonowania pozostałych dwóch sfer władzy państwowej: ustawodawczej i sądowniczej. W uproszczeniu przyjąć można, że uprawnienia głowy państwa dzieli się na cztery kategorie: związane ze sprawowaniem najwyższego organu rządowego (rola konstytucyjnego gwaranta, stanowiącego ,żywy” symbol naro$\mathrm{du}$ ); związane z tworzeniem prawa (w postaci ogłaszania ustawodawstwa i podpisywania umów międzynarodowych); odnoszące się do pełnienia jurysdykcji nad organami administracyjnymi i politycznymi rządu (m.in. mianowanie urzędników oraz dotyczące sprawowania kontroli nad państwowym monopolem w zakresie legalnego stosowania przymusu z użyciem siły fizycznej (poprzez chociażby formalne dowodzenie siłami zbrojnymi [Miller (red.) 2010: 131].

W odniesieniu do gubernatora generalnego Nowej Zelandii zwykło się wskazywać trzy rodzaje pełnionych przez niego funkcji, a mianowicie ceremonialne, symboliczne oraz konstytucyjne. Pierwsza grupa uprawnień dotyczy jego funkcjonowania jako faktycznie głowy państwa. Obejmuje ona wszelkie oficjalne obowiązki, które gubernator generalny sprawuje na mocy przekazanych mu uprawnień monarszych, takich jak otwieranie sesji parlamentarnych, odbieranie listów uwierzytelniających dyplomatów akredytowanych w Nowej Zelandii czy też przyjmowanie wizytujących szefów głów państw obcych. Funkcje symbo- 
liczne gubernatora generalnego wiążą się z jego działaniami jako bezstronnego symbolu konstytucyjnego porządku, uosabiającego wartości i cele narodu nowozelandzkiego. Realizowanie tych czynności odbywa się poprzez aktywność gubernatora generalnego starającego się kreować i podtrzymywać kontakty ze społecznością nowozelandzką.

Natomiast trzeci rodzaj funkcji pełnionych przez gubernatora generalnego ma charakter stricte konstytucyjny, a zatem tyczy się wszystkich uprawnień wynikających z konstytucji. Od strony formalnej zakres tychże kompetencji pozostaje bardzo rozległy, jako że zawiera w sobie szereg uprawnień na czele z przewodniczeniem Radzie Wykonawczej; powoływaniem premiera i jego ministrów, mianowaniem sędziów i innych wysokich urzędników państwowych; zwoływaniem, rozwiązywaniem i przedłużaniem sesji parlamentarnych, jak też udzielaniem sankcji królewskiej projektom ustaw [Angelo 2011: 55]. Uprawnienia, o których mowa, wpisane są niejako w instytucję Korony, stanowiąc uprawnienia rządowe ('prerogative powers').

Pewną pozostałością rozległych uprawnień gubernatora generalnego z okresu kolonialnego są tzw. uprawnienia zastrzeżone ('reserve powers of the prerogati$v e$ '). O ile reprezentant suwerena nie angażuje się w bieżącą politykę, o tyle poprzez uprawnienia zastrzeżone dysponuje możliwością reakcji w sytuacji nagłego kryzysu lub celem zapobieżenia mu. Zgodnie z konwenansem konstytucyjnym uprawnienia te mieszczą się w sferze wyłącznej aktywności ministrów Korony lub głowy państwa, działającej za ich radą [Miller (red.) 1997: 56]. To, co formalnie przysługuje gubernatorowi generalnemu jako osobistemu reprezentantowi suwerena, w praktyce ustrojowej zostało ograniczone. Na jego decyzje w zasadniczym stopniu wpływa stanowisko większości parlamentarnej, które z kolei podporządkowane jest preferencjom szefa rządu i jego ministrom.

Zauważyć trzeba, że urząd gubernatora generalnego podlegał wielowiekowej ewolucji, w rezultacie której przestał być on postrzegany jako lokalne przedstawicielstwo rządu imperialnego, a stał się reprezentacją Korony. W określonym zakresie pierwotnie wyrażane wartości i postawy brytyjskiego społeczeństwa zostały przetransponowane do Nowej Zelandii. Proces określany mianem unarodowienia (patriation) mający na celu dopasowanie gubernatora generalnego do lokalnej kultury wpłynął na zmianę charakteru oraz stylu sprawowania przez niego urzędu [Cox 2008: 192-193]. Od 1967 r. urząd gubernatora generalnego piastują Nowozelandczycy (formalnie od 1941 r., a nieformalnie od 1910 r.), mianowani przez królową za radą premiera Nowej Zelandii. Fakt, iż objęcie obowiązków gubernatora generalnego następuje „,z upodobania monarchy” ('At Her Majesty's pleasure') powoduje, iż w praktyce możliwe jest przedłużenie udzielonych mu na okres 5 lat pełnomocnictw do sprawowania urzędu.

Status gubernatora generalnego stanowi zatem pochodną jego pozycji na szczycie władzy wykonawczej oraz pełnienia roli przedstawiciela suwerena. O tym, że jest to $\mathrm{w}$ istocie pozycja fasadowa $\mathrm{w}$ systemie organów władzy państwowej przesądziły zasadniczo dwa czynniki: historyczny, związany z przeobra- 
żeniem się Imperium Brytyjskiego w luźny związek państw, które zachowały między sobą jedynie symboliczne więzi, oraz ustrojowy, wynikający z założeń, które legły u podstaw kreowania urzędu głowy państwa, wyposażonej w funkcje o charakterze reprezentacyjnym i protokolarnym [Jakubiak (tłum.) 2018: 34].

Warto podkreślić szczególne znaczenie Korony jako instytucji reprezentowanej przez monarchę (suwerena), upoważniającej rząd do sprawowania władzy w Nowej Zelandii. Pojęcie „Korony” jest znacznie szersze niż „monarcha” czy „suweren”, czemu sprzyjał fizyczny brak suwerena, jak i relatywnie słaba pozycja gubernatora generalnego. Tym samym Korona jako polityczny byt stanowiący rdzeń funkcji rządu stała się elementem silniejszym od monarchy (suwerena). Obecna rola królowej Nowej Zelandii wynika z ewolucyjnego rozwoju własnych, narodowych koncepcji Korony ('national Crown') przez poszczególne brytyjskie dominia. Wszelkie wcześniejsze zobowiązania wobec jednej Korony Brytyjskiej (British Crown), stały się odpowiedzialnością wyłącznie względem Korony Nowej Zelandii (New Zealand Crown). Niemniej jednak symboliczne oraz praktyczne więzy z brytyjskim monarchą przetrwały [Cox 2008: 166].

System rządów w Nowej Zelandii z gubernatorem generalnym jako de facto głową państwa jest określany mianem „ulokowanej monarchii” ('localised monarchy'), co ma nawiązywać do ostatniego etapu procesu określonego przez Andrew Ladleya jako „udomowienie Korony Zjednoczonego Królestwa w Nowej Zelandii" ('final domestication') [Miller (red.) 1997: 55]. Jest to konstrukcja, która nadała gubernatorowi generalnemu o wiele bardziej doniosłą z konstytucyjnego punktu widzenia pozycję niż ta, którą formalnie zajmuje Królowa jako głowa nowozelandzkiego państwa.

Zasadniczo pozycja ustrojowa gubernatora generalnego nie zmieniła się nawet po wprowadzeniu mieszanego systemu wyborczego (Mixed-Member Proportional System), co zwolennicy ustroju republikańskiego w Nowej Zelandii postrzegali jako ostateczny dowód na utratę brytyjskiej tożsamości [Milani 2011]. Wzmocnieniu uległa jedynie rola parlamentu, a zadaniem gubernatora generalnego po 1993 r. stało się moderowanie procesu zawierania powyborczych sojuszy celem utworzenia rządu. W warunkach obowiązywania nowej ordynacji wyborczej konstytucyjna pozycja gubernatora generalnego zbliżona została do zajmowanej obecnie przez suwerena w Zjednoczonym Królestwie [Cox 2002a: 436].

Biorąc pod uwagę prawne podstawy funkcjonowania urzędu gubernatora generalnego należy podkreślić, że wprowadzenie ustroju republikańskiego oznaczałoby przede wszystkim konieczność wprowadzenia zmian do Ustawy Konstytucyjnej. Na mocy art. 14 ust. 1 tego aktu struktura parlamentu jest dwusegmentowa: poza Izbą Reprezentantów w jego składzie znajduje się również suweren, którego uprawnienia są wykonywane przez gubernatora generalnego. Monarcha stał się w pełni suwerenem „w parlamencie nowozelandzkim”, pełniącym jednocześnie formalne funkcje głowy państwa. Rozważając kwestię zmiany ustroju wypada wskazać, że nie da się usunąć jednego z elementów parlamentu bez naruszenia całej konstrukcji tego organu. 
Skoro pozycję ustrojową monarchy regulują przed wszystkim konwenanse konstytucyjne, korzysta on z przysługujących mu uprawnień suwerena jedynie w sensie prawnym. W polityczny atrybut suwerenności wyposażony został naród, dlatego też zamiar urzeczywistnienia tak fundamentalnej zmiany konstytucji pociągnąłby za sobą konieczność odwołania się do instytucji referendum. Byłoby to notabene zgodne z przewidywanym stanowiskiem powołujących się na prawo zwyczajowe sądów, które mogłyby nie uznać ustawy, wprowadzającej republikanizm w Nowej Zelandii [Cox 2002b: 141-142].

Zagadnienie to powinno być rozpatrywane w szerszym kontekście obowiązywania formuły trójpodmiotowej suwerenności króla w parlamencie, którą odzwierciedla trójsegmentowa konstrukcja organu ustawodawczego. W oryginalnej wersji brytyjskiej monarcha wraz z izbami parlamentarnymi zaliczony został do piastunów władzy najwyższej. Każdy z tych podmiotów ma równą pozycję, a zatem suwerenne są ich wspólnie uzgodnione decyzje. W zmodyfikowanej wersji nowozelandzkiej, od 1950 r. mamy do czynienia z unikameralną legislatywą, toteż suwerenna jest każda wspólna decyzja Izby Reprezentantów i monarchy [Bernacki, Walaszek (red.) 2012: 1045]. Usunięcie choćby jednego z elementów konstytuujących parlament pozbawiłoby słuszności tezę, że każda decyzja organu ustawodawczego jest suwerenna, gdyż opiera się na zasadzie suwerenności.

Kwestia zmiany ustroju w ujęciu prawnym nie może sprowadzić się zatem jedynie do zlikwidowania instytucji monarchy czy też zastąpienia suwerena prezydentem, mimo że pozornie mogłoby to wydawać się łatwiejsze z uwagi na brak ustawowej ochrony pozycji Korony. Wprowadzenie republikańskiej głowy państwa wiązałoby się z koniecznością zmiany charakteru nowozelandzkiej konstytucji. Przyjęcie ustawy zasadniczej w znaczeniu formalnoprawnym oznaczałoby zerwanie z modelem brytyjskim, w ramach którego jedynie częściowo materie konstytucyjne uległy kodyfikacji. W zamian za to ustanowione zostałyby normy wyposażone $\mathrm{w}$ najwyższą rangę prawną, przyjmowane i zmieniane $\mathrm{w}$ drodze szczególnego, kwalifikowanego trybu. Jest to rozwiązanie powszechnie znane w państwach demokratycznych oparte na przekonaniu, że wprowadzanie procedur utrudniających zmianę konstytucji takich jak wymóg kwalifikowanego kworum czy większości, gwarantuje temu aktowi większą trwałość od ustaw zwykłych [Balicki, Jabłoński (red.) 2018: 65].

Warto przy tym dostrzec, że wskazanie trybu powoływania i odwoływania republikańskiej głowy państwa z jednej strony zapewniłoby jej prawnie określoną, a przez to chronioną pozycję ustrojową, z drugiej zaś w sytuacji niewłaściwego wykonywania obowiązków, instrumenty prawne służące egzekwowaniu odpowiedzialności. Jednakże pewne elementy, wynikające z recypowania westminsterskiej kultury prawnoustrojowej wraz z kodyfikacją konstytucji, zostałyby bezpowrotnie utracone. O unikatowości przyjętych rozwiązań ustrojowych stanowią bowiem zwyczaj i tradycja.

Zaznaczyć należy, że zarówno obdarzenie republikańskiej głowy państwa zbyt daleko idącymi uprawnieniami, jak i jej istotne osłabienie pociągnęłyby 
określone skutki prawne. W sytuacji nadania instytucji nowej głowy państwa nieznacznych w porównaniu do obecnych prerogatyw, usunięty zostałby de facto ostatni element kontroli (check) nad rządem. Znaczące zwiększenie uprawnień głowy państwa byłoby przyczynkiem do zmiany całego systemu rządów. Stanowiłoby to krok w kierunku formuły prezydenckiej, w ramach której głowa państwa pełniłaby jednocześnie funkcje szefa rządu. Takie rozwiązanie jako najbardziej radykalne odstępstwo od założeń westminsterskich, wydaje się jednak na obecny moment wysoce nieprawdopodobne [Wood, Rudd 2004: 49-50].

Obecnie gubernator generalny, formalnie mianowany przez nominalną głowę państwa, faktycznie powoływany jest przez rząd. Zgodnie z panującym konwenansem konstytucyjnym monarcha zawsze akceptuje kandydata przedstawianego na stanowisko szefa rządu. Przyjęcie rozwiązania polegającego na pozostawieniu wyboru nowej głowy państwa w gestii parlamentu byłoby zatem bliskie obecnym ustaleniom. Następowałoby to na skutek decyzji partii politycznej, dysponującej większością w parlamencie. W propozycji przedstawionej przez Palmera i Butlera [2016: 94] jako sposób powołania w miejsce królowej nowej, głowy państwa ('Head of State') wskazane zostało wolne głosowanie ('free vote'). W praktyce oznacza to głosowanie bez zachowania dyscypliny partyjnej, a jedynie w zgodzie z własnymi indywidualnymi preferencjami. W założeniu miałoby to wyeliminować przekonanie, że głowa państwa jest powoływana tylko przez jedno rządzące ugrupowanie polityczne, a zarazem wzmocnić niezależność i neutralność tego stanowiska.

Odstąpienie od głosowania bezpośredniego obywateli w projekcie Palmera i Butlera uzasadnione zostało w dwojaki sposób. Po pierwsze, nowa głowa państwa zostałaby wyposażona w zasadniczo podobne, choć nieidentyczne uprawnienia do tych, jakie posiada obecnie gubernator generalny. Tym samym byłaby zupełnie pozbawiona uprawnień wykonawczych. Po drugie, bezpośredni wybór wiązałby się z uzyskaniem mandatu społecznego do rządzenia, z którego głowa państwa musiałaby się w ciągu swojej 5-letniej kadencji wywiązać przed narodem. To w praktyce zwiększyłoby ryzyko upolitycznienia urzędu, pozostając w kontrze do podstawowego założenia względem głowy państwa, a mianowicie, że powinna ona stanowić symbol jedności i kulturowego dziedzictwa. Nie bez znaczenia byłby także argument wskazujący na wysokie koszty związane z organizacją i przeprowadzeniem w pełni demokratycznych, wolnych i bezpośrednich wyborów.

\section{KONSEKWENCJE POLITYCZNE ZNIESIENIA MONARCHII}

Odnosząc się do skutków politycznych wprowadzenia ustroju republikańskiego w Nowej Zelandii warto za punkt wyjścia uczynić kwestię relacji między Maorysami a Koroną. Nie ma bowiem wątpliwości, że w największym, jeśli nie podstawowym zakresie, implikacje tej potencjalnej zmiany ustrojowej dotknęłyby szczególnego związku pomiędzy społecznością maoryską a Koroną. Maorysi 
jako autochtoniczni mieszkańcy Nowej Zelandii, przez długi czas pozostawali w sporze ze stroną brytyjską. Czyniąc zadość wybujałym aspiracjom Brytyjskiego Imperium, podejmowano wysiłki mające na celu zasymilowanie rdzennych mieszkańców nowej kolonii. Część wodzów maoryskich 28 października 1835 r. podpisała Deklarację Niepodległości Nowej Zelandii (Declaration of the Independence of New Zealand). Korona Brytyjska zyskała status protektora niezależności nowopowstałego państwa [Palmer 2008: 40].

Aktem uznawanym za podwalinę narodu nowozelandzkiego, podstawę stosunków rasowych w Nowej Zelandii, a jednocześnie dokument, w którym wyrażona została symboliczna jedność plemion, stał się Traktat z Waitangi zawarty 6 lutego 1840 r. Jest on również zwany Wielką Kartą Maoryską (Maori Magna Carta) w nawiązaniu do angielskiej Wielkiej Karty Swobód (Magna Charta Libertatum) z $1215 \mathrm{r}$. W Traktacie z Waitangi zawarto historyczne porozumienie między Maorysami a Brytyjczykami w celu budowy państwa narodowego. Dokument ten odzwierciedlał ówczesne rozumienie zasad konstytucyjnych, a zwłaszcza właściwych relacji między poddanymi a Koroną oraz między osadnikami a ludami rdzennymi.

Traktat z Waitangi pomimo, że z ustrojowo-politycznego punktu widzenia był niezmiernie ważny, nie stał się częścią powszechnie obowiązującego prawa. Wyrażał wieloletnie zasady prawa zwyczajowego i rozwijającą się praktykę rządów imperialnych w traktowaniu ludów tubylczych, chociaż żadne prawo maoryskie nie znalazło uznania na gruncie kolonialnego systemu prawnego [Cox 2013: 53]. Wypada jednak wskazać, że z czasem Traktat zaczął być uważany przez sądy za element niezbędny przy interpretowaniu ustaw. Ustanowione dla Maorysów w 1841 r. prawo odwołania się do Komitetu Sądowego Tajnej Rady (Judicial Committee of the Privy Council) dla Nowej Zelandii postrzegane było jako możliwość bezpośredniej apelacji, przysługującej każdemu podmiotowi Korony na podstawie postanowień Traktatu z Waitangi.

Powołany w 1975 r. Trybunał Waitangi (Waitangi Tribunal), będący w zasadzie stałą komisją śledczą, odgrywa decydującą rolę w dochodzeniu maoryskich roszczeń wynikających z domniemanych naruszeń Traktatu. Fundamentalną zmianą, polegającą na rozszerzeniu jurysdykcji Trybunału Waitangi o wszelkie kwestie wynikłe od momentu podpisania Traktatu z Waitangi, była nowelizacja ustawy o Traktacie z Waitangi z 1985 r. (Treaty of Waitangi Amendment Act 1985). Wspomnieć trzeba także o zniesieniu w 2003 r. prawa odwołania się do Komitetu Sądowego z siedzibą w Londynie wraz z ustanowieniem Sądu Najwyższego, który pełni rolę najwyższego sądu w ramach nowozelandzkiej judykatury.

Bez wątpienia Korona od 1840 r. jako jeden z sygnatariuszy Traktatu, pozostaje symbolicznie ważna dla społeczności Maorysów. Traktat z Waitangi, postrzegany jako ,żywy dokument” ('living document'), ustanowił standard sprawiedliwości między Koroną a Maorysami. Wywodzone z niego zasady obejmują partnerstwo oparte na dobrej wierze i współpracy wzajemnej, obowiązek czynnej ochrony interesów Maorysów, a także naprawy szkód wyrządzonych w związku 
z łamaniem postanowień Traktatu. Natomiast dość powszechne założenie, że stanowi on osobistą umowę maoryskich wodzów z królową Wiktorią a każda próba usunięcia suwerena byłaby postrzegana przez Maorysów jako zagrożenie dla ich praw wynikających z tego dokumentu, nie wydaje się uzasadnione.

Dla rozstrzygnięcia tej kwestii istotne jest podkreślenie, że zobowiązania Korony, które wynikają z Traktatu z Waitangi, dotyczą obecnie wyłącznie nowozelandzkiego rządu. W ten sposób jest on traktowany jako podmiot, który przejął zobowiązania monarchy brytyjskiego wobec społeczności maoryskiej. Zniesienie monarchii mogłoby zatem zyskać poparcie Maorysów jako strony Traktatu, aczkolwiek wymagałoby podjęcia z nimi formalnych konsultacji. Osobiste zaangażowanie suwerena jako sygnatariusza tej fundamentalnej umowy pozostaje ważne dla wielu Maorysów, ale wprost nie przekłada się na poziom poparcia Maorysów dla monarchii. Dla nich bowiem ostatecznie rozstrzygające jest to, aby wraz ze zmianą ustroju rząd był w stanie zagwarantować im dalsze uznawanie i egzekwowanie praw oraz utrzymanie obecnie posiadanego specjalnego statusu, przyznanego im właśnie na mocy postanowień Traktatu z Waitangi [Trainor (red.) 1996: 118-120].

W istocie zatem do Maorysów należeć będzie decyzja czy wypełnianie zobowiązań wynikających z Traktatu z Waitangi będzie w dalszym ciągu wymagało kontynuowania idei Korony jako partnera traktatowego. Ogólnie jednak pogląd, że republika stanowi zagrożenie dla Maorysów, nie jest powszechnie uznawany za słuszny, jeśli tylko wprowadzenie ustroju republikańskiego nie miałoby być próbą zamaskowania zamiaru odstąpienia od realizacji przez rząd zobowiązań wynikających z Traktatu. Część Maorysów postrzega republikę jako możliwość ustanowienia przez swoje plemię własnego państwa. Nie brakuje jednak wybitnych przywódców maoryskich, którzy wyrażają otwarty sprzeciw wobec wprowadzenia ustroju republikańskiego w Nowej Zelandii. Idea republikanizmu oparta na nacjonalizmie, który traktowany był jako swoisty sojusznik przeciwko rządowi kolonialnemu, padła wprawdzie na dość podatny grunt, ale do zniesienia monarchii okazał się niewystarczający.

Jednym z dość często przytaczanych argumentów na rzecz republiki jest wskazanie, że wzmocniłoby to tożsamość narodową i postrzeganie Nowej Zelandii jako państwa niepodległego [Patel 2018: 434-436]. Zaznaczyć trzeba, że to nie Maorysi, lecz Nowozelandczycy europejskiego pochodzenia a zwłaszcza osoby urodzone w Wielkiej Brytanii, stanowią grupę społeczną, która w większym stopniu popiera monarchię. Można to interpretować jako dostrzeżenie w tym mistycyzmu i symboliki dawnego statusu Nowej Zelandii: odległej i szczególnie lojalnej kolonii brytyjskiej. Potwierdziły to wyniki badania przeprowadzonego w 2008 r., w którym łącznie 49,6\% respondentów opowiedziało się za monarchią (w tym 52\% europejskich Nowozelandczyków i 44\% Maorysów), natomiast 32,8\% ankietowanych wyraziło poparcie dla republiki [R. Miller (red.) 2012: 136-138].

Jak wskazywał premier Jim Bolger, który już w 1994 r. postulat wprowadzenia republiki w Nowej Zelandii uczynił jednym z elementów programu wy- 
borczego Partii Narodowej, „niewłaściwe” (inappropriate) jest dla „królowej Anglii” wyznaczanie gubernatora generalnego, który ,wykonywałby w Jej imieniu uprawnienia monarsze w Nowej Zelandii" [J. Bolger 1997: 6]. Twierdzenie, że tożsamość narodowa wymaga ustanowienia nowozelandzkiej głowy państwa, chociaż popierane zarówno przez szefową rządu z ramienia Partii Pracy w latach 1999-2008, Helen Clark, jak i stojącego na czele gabinetu Partii Narodowej, Johna Keya, w latach 2008-2016, nie łączyło się z wyraźnym wsparciem sprawy republikańskiej. Można domniemywać, że spowodowane to było stosunkowo małym poparciem, jakim idea ta cieszyła się wśród Nowozelandczyków [Zięba (red.) 2013: 118].

Inaczej sytuacja wyglądała w sąsiedniej Australii, gdzie działania na rzecz spopularyzowania idei republikańskiej prowadzone były od początku lat 90 . XX w. Za moment kulminacyjny tego procesu uznać wypada referendum w sprawie zmiany ustroju z listopada 1999 r. Mimo, że zakończyło się fiaskiem (jedynie 45\% głosujących opowiedziało się za republikańską formą rządów), idea zniesienia monarchii i powołania urzędu prezydenta, wybieranego spośród obywateli australijskich, nie upadła. Przeciwnie, kwestia ta została podjęta przez komisję senacką, która w 2004 r. opublikowała raport pt. „Droga do republiki” ('The road to a republic').

Nadal działalność na terytorium Australii prowadzi Ruch Republikański ( $A u$ stralian Republican Movement) [Kandzia-Poździał, Siekiera (red.) 2017: 47-49]. Ma on swój odpowiednik w Nowej Zelandii w postaci grupy New Zealand Republic, utworzonej w 1994 r. (w latach 1999-2014 występującej pod nazwą Republikański Ruch Aotearoa Nowa Zelandia). Warto dodać, że wbrew założeniom premiera Bolgera, że Nowa Zelandia do 2000 roku zerwie więzi z monarchią brytyjską i stanie się republiką, jedyny jak dotąd projekt ustawy referendalnej w tej sprawie (Head of State Referenda Bill), złożony w 2009 r. przez deputowanego Keitha Locka, został odrzucony już w pierwszym czytaniu.

Symbolizm, chociaż ważny, nie determinuje wprost kwestii zniesienia monarchii jako „zerwania więzów kolonialnych”, aby wzmocnić narodowa tożsamość Nowozelandczyków. Powodów takiego stanu rzeczy należy upatrywać głównie w tym, że symbolika Korony stała się z czasem istotnym elementem w dialogu pomiędzy Maorysami a rządem. Korona jako instytucja odrębna od monarchii zaczęła „żyć własnym życiem”. Co więcej, upatrywano w niej skutecznego narzędzia do nabycia politycznej niezależności, obawiając się zarazem utraty „życzliwej protekcji”, jaką Nowej Zelandii zapewniały prawno-instytucjonalne więzy z Koroną [Eska 2012: 417]. Istotną rolę odegrał przy tym brak obowiązywania formalnoprawnej konstytucji, gdyż kontynuowano istnienie Korony w postaci tradycyjnej funkcji konstytucyjnego centrum.

Obecnie kwestią zasadniczą pozostaje określenie tego, co w aspekcie przyjęcia ustroju republikańskiego mogłoby zastąpić Koronę jako symbol na gruncie obowiązującego ustawodawstwa i praktyki politycznej. Według Palmera i Butlera [2016] substytutem Korony jako bytu „zbyt skomplikowanego, niejednoznacz- 
nego i mistycznego", powinno stać się „państwo” ('state'). Od strony formalnej zerwanie więzi kolonialnych stanowiłoby swoistą formę pełnej dekolonizacji, chociaż ani w republikańskim projekcie konstytucji z 2016 r., ani też w statucie ruchu prorepublikańskiego nie zawarto postulatów wyjścia Nowej Zelandii ze Wspólnoty Narodów (Commonwealth of Nations).

\section{ZAKOŃCZENIE}

Na podstawie wyników ankiety z kwietnia 2019 r. uzasadnione jest twierdzenie, że środowisko społeczno-polityczne Nowej Zelandii uległo w ostatnich dwóch dekadach pewnej dynamice. Rezultaty badania wykazały bowiem, że $55 \%$ społeczeństwa chce Nowozelandczyka wybieranego przez większość 2/3 parlamentu, a jedynie 39\% głosujących życzyłoby sobie na tym stanowisku następnego monarchy brytyjskiego. Poparcie dla Nowozelandczyka jako głowy państwa, wybieranego bezpośrednio przez obywateli, jak i w drodze głosowania organu ustawodawczego, było najsilniejsze wśród Maorysów (80\%) i młodych respondentów w wieku 18-30 lat (76\%) [Media release: Opinion Poll-Majority of New Zealanders want a New Zealand head of state WWW].

Zgodnie z tym należy stwierdzić, że takie czynniki, jak zmiany demograficzne oraz rosnąca imigracja, skutkujące osłabieniem przywiązania do monarchii, mogą przyczynić się do wzmocnienia chęci zmiany ustroju w Nowej Zelandii. $\mathrm{Z}$ większym prawdopodobieństwem byłaby to jednak stopniowa transformacja, w efekcie której utrwalony układ sił w podziale władzy, determinowany założeniami demokracji westminsterskiej, zostałby do pewnego stopnia zachowany. Pozwoliłoby to utrzymać wyłanianego przez legislatywę prezydenta o stosunkowo niewielkich kompetencjach, niezdolnego do wywierania realnego wpływu na funkcjonowanie władzy wykonawczej.

Można także założyć, że prawdopodobną drogą dalszego rozwoju konstytucyjnego Nowej Zelandii nie będzie zniesienie monarchii, lecz jedynie nadanie Koronie bardziej narodowej i współczesnej formy. Niezbędne dla dalszego funkcjonowania narodu i państwa byłoby zastąpienie nowymi treściami obecnej symboliki związanej z głową państwa. Kwestia ta zyskuje na znaczeniu w kontekście słów obecnej (od 2017 r.) premier, Jacindy Ardern, która przyznała, że ma przeczucie, iż Nowa Zelandia „za jej życia może stać się republiką” [Roy 2018]. Szefowa rządu podkreśliła przy tym rangę Traktatu z Waitangi, jako „specjalnego porozumienia”, które położyło fundament pod szczególny związek społeczności maoryskiej i Korony. Potwierdza to, że kluczem do rozwiązania sprawy są Maorysi - ich specjalny status zapewnia im realną możliwość wpływu na to, czy istniejące status quo zostanie utrzymane, czy też obecny system polityczno-ustrojowy Nowej Zelandii w przyszłości ulegnie zmianie. 
Title: Legal and political consequences of introducing the republican form of government for the political position of the head of state in New Zealand

Abstract: The analysis concerns the legal and political implications of a potential political change in New Zealand on the functioning of the head of state. According to the thesis statement, the special status of the Maori may complicate the further development of events, weakening the willingness to introduce a republic in this country. In this study, the author has adopted the following research methods: an analysis of legal sources and a critical analysis as well as a descriptive method. The text is divided into two main parts and the introduction and the conclusion.

Keywords: republic, head of state, Treaty of Waitangi, Maori, New Zealand

\section{BIBLIOGRAFIA}

1. Angelo A., 2011, Constitutional Law in New Zealand, Kluwer Law International, Alphen aan den Rijn.

2. Bisztyga A., Wojtczak D., 2018, Teoretyczne i komparatystyczne uwagi o trybie zmiany konstytucji i jej preambuly, [w:] Dookoła Wojtek ... Księga pamiątkowa poświęcona Doktorowi Arturowi Wojciechowi Preisnerowi, red. W. Bernacki, A. Walaszek, Wyd. Uniwersytetu Wrocławskiego, Wrocław, s. 65-77.

3. Bolger J., 1997, Daily News z 08.05.1997.

4. CONSTITUTION ACT (1986), http://www.legislation.govt.nz/act/public/1986/0114/latest/ DLM94204.html z 13.12.1986.

5. Cox N., 2013, Proposed Constitutional Reform in New Zealand: Constitutional Entrenchment, Written Constitutions and Legitimacy, "The Round Table: The Commonwealth Journal of International Affairs", 102 (1), s. 51-70.

6. Cox N., 2008, A Constitutional History of the New Zealand Monarchy: The Evolution of the New Zealand Monarchy and the Recognition of an Autochthonous Polity, VDM Verlag Dr. Müller, Saarbrücken.

7. Cox N., 2002a, The Effect of the Advent of the Mixed-Member Proportional Voting System Upon the Role of the Governor-General of New Zealand, "Bond Law Review", 14 (2), s. $423-441$.

8. Cox N., 2002b, Republican Sentiment in the Realms of the Queen: The New Zealand perspective, "Manitoba Law Journal", 29 (1), s. 121-147.

9. Cox N., Miller R., 2010, Monarchy or Republic?, [in:] New Zealand Government and Politics, red. R. Miller, Oxford University Press, Auckland, s. 130-144.

10. Dańda A., 2017, Monarchia czy kryptorepublika? Monarcha i gubernator generalny we wspótczesnym systemie ustrojowym Zwiazku Australijskiego, [w:] Australia w XX i XXI wieku. Polityka, historia i kultura, red. A. Kandzia-Poździał, J. Siekiera, Wyd. UŚ, Katowice, s. 39-55.

11. Dańda A., 2013, Ewolucja pozycji ustrojowej generalnego gubernatora w dominiach brytyjskich, [w:] Konstytucjonalizm w państwach anglosaskich, red. A. Zięba, Wyd. UJ, Kraków, s. 103-122.

12. Eska J., 2012, Ewolucja ustroju politycznego oraz statusu prawnomiędzynarodowego Nowej Zelandii, „Politeja. Pismo Wydziału Studiów Międzynarodowych i Politycznych Uniwersytetu Jagiellońskiego", nr 21, s. 409-421.

13. Jakubiak Ł. thum., 2018, Akty konstytucyjne Nowej Zelandii, Wyd. Sejmowe, Warszawa.

14. Ladley A., 1997, The Head of State: The Crown, The Queen and The Governor-General, [in:] New Zealand Politics in Transition, red. R. Miller, Oxford University Press, Auckland, s. 51-61. 
15. Media release: Opinion Poll-Majority of New Zealanders want a New Zealand head of state, [online:] http://www.republic.org.nz/latestblog/2019/5/15/media-release-opinion-poll-new-zealanders-want-a-new-zealand-head-of-state z 17.05.2019. [dostęp: 21.12.2020].

16. Milani L.S., 2011, An Evaluation of the Prospect of Republicanism in New Zealand, [online:] https://www.e-ir.info/2011/07/07/an-evaluation-of-the-prospect-of-republicanism-in-new-zealand [dostęp: 19.12.2020].

17. Palmer M.S.R., 2008, The Treaty of Waitangi in New Zealand's Law and Constitution, Victoria University Press, Wellington.

18. Palmer G., Butler A., 2016, A Constitution for Aotearoa New Zealand, Victoria University Press, Wellington.

19. Patel J., 2018, Will New Zealand Inevitably become a Republic, 'Just as Britain Will Be Blurred into Europe"?, "The Round Table”, 107 (4), s. 429-440.

20. Roy E.A., 2018, New Zealand likely to become a republic in my lifetime, Jacinda Ardern says, [online:] https://www.theguardian.com/world/2018/mar/30/new-zealand-likely-to-become-a -republic-in-my-lifetime-says-jacinda-ardern [dostęp: 18.12.2020].

21. ROYAL TITLES ACT (1974), http://www.legislation.govt.nz/act/public/1974/0001/latest/ DLM411814.html z 06.02.1974.

22. Scott K.J., 1962, The New Zealand Constitution, Oxford University Press, Oxford.

23. Tunks A., 1996, Mana Tiriti, [in:] Republicanism in New Zealand, red. L. Trainor, The Dunmore Press, Palmerston North, s. 113-132.

24. Wood G.A., Rudd C., 2004, The Politics and Government of New Zealand: robust, innovative and challenged, University of Otago Press, Dunedin.

25. Zięba A., 2012, Z zagadnień kultury prawnoustrojowej w konstytucjonalizmie Nowej Zelandii, [w:] Amerykomania: ksiega jubileuszowa ofiarowana profesorowi Andrzejowi Mani, t. 2, red. W. Bernacki, A. Walaszek, Wyd. UJ, Kraków, s. 1039-1054. 